\title{
ANALISIS PERANAN KREDIT SEKTORAL DAN PENGARUH BI RATE DALAM MENDORONG PERTUMBUHAN EKONOMI NASIONAL
}

\author{
Irwanramliosman @yahoo>com \\ Shafenti@gmail.com
}

\begin{abstract}
This research discusses about the analysis of the role of sectoral credit and the impact of BI Rate in promoting economic growth in Indonesia with panel data method analysis. Researcher estimates this model by using the structure of stacked panel data and also uses observation period from 2011 to 2015. This panel data also consist of 16 sectors of the economy as the cross section dataset. The objectives of this study are to describe the role of sectoral credit and the impact of BI rate to the GDP In promoting economic growth. Based on fixed effect method by using eviews 9, all independent variables have positive and significant impacts to GDP growth partially and simultaneously. Through this study, researcher expects ministry of finance as the fiscal authority, central bank of Indonesia (monetary authority), and also financial services authority of Indonesia can form a synergy and continuous interaction in designing policies that have impacts on sustainable economic growth in Indonesia
\end{abstract}

Keywords : sectoral credit, BI rate, economic growth, GDP, banking industry

\begin{abstract}
ABSTRAK:Penelitian ini membahas tentang analisis peranan kredit sektoral dan pengaruh BI Rate dalam mendorong pertumbuhan ekonomi nasional dengan menggunakan metode analisis data panel dan jenis struktur data yang digunakan adalah stacked panel data. Periode penelitian dimulai dari tahun 2011 sampai dengan tahun 2015 dengan data cross section-nya terdiri dari 16 sektor. Tujuan dari penelitian ini adalah mengetahui peranan kredit sektoral dan juga pengaruh BI Rate terhadap PDB dalam mendorong pertumbuhan ekonomi. Berdasarkan metode fixed effect yang terpilih dengan alat bantu analisis menggunakan Eviews 9, semua variabel independen pada penelitian ini (kredit sektoral dan BI Rate) secara parsial memberikan pengaruh yang signifikan dan positif terhadap peningkatan PDB. Demikian juga secara simultan seluruh variabel independen berpengaruh secara signifikan terhadap variabel dependen pada penelitian ini. Adapun harapan peneliti terkait hasil penelitian ini adalah perlunya sinergi secara berkesinambungan antara pemerintah, Bank Indonesia, dan juga Otoritas Jasa Keuangan dalam merumuskan kebijakan-kebijakan yang memiliki dampak pada keberlanjutan pertumbuhan ekonomi Indonesia.
\end{abstract}

Kata Kunci : kredit sektoral, BI rate, pertumbuhan ekonomi, PDB, perbankan

\section{PENDAHULUAN}

Perekonomian nasional yang tercermin dari pertumbuhan ekonomi dalam 
hal ini pertumbuhan PDB (produk domestik bruto) menunjukkan tren penurunan salah satunya sebagai dampak dari perlambatan ekonomi dunia akibat krisis di Eropa. Secara keseluruhan, hingga tahun 2015 kinerja pertumbuhan PDB (lihattabel 1) masih dibayang-bayangi oleh ketidakpastian kondisi perekonomian global, khususnya dampak dari pelemahan perekonomian negara-negara maju seperti Jepang, Amerika Serikat, dan kawasan Eropa.

Tabel 1. Perkembangan PDB Indonesia Tahun 2011-2015 atas Dasar Harga Konstan Tahun Dasar 2010 (Milyar Rp)

\begin{tabular}{|c|c|c|}
\hline Tahun & PDB (Miliar Rupiah) & $\begin{array}{c}\text { Pertumbuhan } \\
\text { Ekonomi (\%) }\end{array}$ \\
\hline 2010 & $6.864 .133,1$ & \\
\hline 2011 & $7.287 .635,3$ & 6,17 \\
\hline 2012 & $7.727 .083,4$ & 6,03 \\
\hline 2013 & $8.156 .497,8$ & 5,56 \\
\hline 2014 & $8.566 .271,2$ & 5,02 \\
\hline 2015 & $8.976 .931,5$ & 4,79 \\
\hline & & Rata-rata $=\mathbf{5 , 5 1}$ \\
\hline
\end{tabular}

Sumber : Badan Pusat Statistik, data diolah

Sektor keuangan sebagai salah satu sektor yang memegang peranan yang cukup signifikan dalam memacu pertumbuhan ekonomi negara tentunya diharapkan dapat menjadi lokomotif pertumbuhan sektor-sektor ekonomi melalui dukungan pembiayaan akumulasi kapital dan juga mendorong inovasi teknologi. Lebih tepatnya, sektor keuangan mampu memobilisasi tabungan dan menyalurkannya kepada pihak-pihak yang membutuhkan melalui kredit.

Di Indonesia, sektor keuangan digerakkan oleh dua lembaga keuangan yaitu lembaga perbankan yang terdiri dari bank-bank umum dan lembaga non perbankan yang terdiri dari pasar modal, lembaga pembiayaan, asuransi, dana pensiun dan pegadaian. Perkembangan sektor keuangan selain dipengaruhi oleh faktor internal seperti peraturan perbankan dan pasar modal juga dipengaruhi oleh faktor lain, seperti perkembangan sektor riil, regulasi pemerintah di bidang ekonomi, perkembangan sosial masyarakat, politik dan demokrasi serta dunia internasional.

Perkembangan sektor perbankan dimana bank memiliki fungsi pokok sebagai agen pembangunan maupun financial intermediary merupakan salah satu pendukung usaha pembangunan tersebut. Keberadaan dunia usaha tidak terlepas dari sektor perbankan yang ada. Dalam hal ini, perkembangan dunia usaha perlu mendapat perhatian yang serius guna meningkatkan kemampuan para pengusaha sehingga dapat bersaing di pasar regional maupun internasional. Kebutuhan dana yang tidak sedikit untuk pembangunan di 
berbagai sektor usaha dan industri sangat ditentukan oleh sektor perbankan. Hal ini, terlihat jelas adanya perkembangan jumlah kredit perbankan sebagai sumber pembiayaan bagi sektor-sektor tersebut sehingga dapat memengaruhi pertumbuhan ekonomi dan tentunya sistem perekonomian nasional.

Selain itu, peranan Bank Indonesia dengan instrumen kebijakan moneternya melalui penetapan suku bunga acuan BI Rate juga memiliki pengaruh dalam dinamika perekonomian nasional dan juga penyaluran kredit. Secara teoritis, apabila BI Rate menurun maka akan mendorong turunnya bunga simpanan dan bunga pinjaman (kredit) perbankan yang dapat menstimulus dunia usaha dalam menaikkan kapasitas produksi yang nantinya akan berdampak pada peningkatan pertumbuhan ekonomi.

Namun bila melihat dari dampak pasca krisis keuangan global pada tahun 2008 yang bermula dari subprime mortgage crisis yang terjadi di Amerika Serikat pada tahun tersebut, tatkala The Fed mulai secara perlahan menaikkan suku bunganya melalui instrumen Federal Fund Rate (FFR), Bank Indonesia mengambil kebijakan untuk mempertahankan suku bunga acuan yang cukup tinggi dengan tujuan untuk mencegah terjadinya keluarnya modal asing (capital outflow/capital flight) dari Indonesia meskipun kebijakan ini tentunya memiliki dampak positif dengan tersedianya dana atau modal yang dapat digunakan dunia usaha di Indonesia untuk mengembangkan usahanya yang nantinya dapat memberikan pengaruh positif terhadap indikator ekonomi makro Indonesia seperti tingkat pertumbuhan, akan tetapi tidak menutup adanya rasa kekecewaan dari pelaku dunia usaha yang kesulitan mendapat kredit dengan suku bunga rendah dari perbankan.

\section{Rumusan Masalah}

Dari uraian yang tersebut di muka, maka dapat dirumuskan masalahnya sebagai berikut:

1. Bagaimanakah peranan kredit sektoral dalam mendorong pertumbuhan ekonomi nasional selama tahun 2011-2015?

2. Bagaimanakah pengaruh perkembangan BI Rate terhadap pertumbuhan ekonomi nasional selama tahun 2011-2015?

3. Bagaimanakah melakukan estimasi dampak secara rata-rata dari variabel kredit sektoral dan BI Rate terhadap pertumbuhan ekonomi nasional selama tahun 2011-2015 dengan menggunakan beberapa estimasi model yang ada?

\section{Tujuan Penelitian}

Sesuai dengan rumusan masalah di atas, maka tujuan dari penelitian ini adalah:

1. Mengetahui dan mendalami karakteristik pertumbuhan ekonomi nasional serta faktor-faktor yang memengaruhinya dengan menggunakan modelmodel yang ada.

2. Untuk mengetahui pengaruh BI Rate dan peranan kredit sektoral dalam mendorong pertumbuhan ekonomi nasional selama periode tahun 20112015. 


\section{TINJAUAN TEORITIS \& HIPOTESIS}

\section{Teori-Teori Pertumbuhan Ekonomi}

Teori pertumbuhan ekonomi diartikan sebagai penjelasan mengenai faktorfaktor apa yang menentukan kenaikan output perkapita dalam jangka panjang dan bagaimana faktor-faktor tersebut berinteraksi satu sama lain sehingga terjadi proses pertumbuhan. Secara umum teori-teori ini dapat dikelompokkan menjadi

: (1) Teori Pertumbuhan Ekonomi Klasik, (2) Teori Pertumbuhan Ekonomi NeoKlasik, dan (3) Teori Pertumbuhan Ekonomi Modern

\section{Produk Domestik Bruto (PDB)}

Salah satu indikator penting untuk mengetahui tingkat pertumbuhan ekonomi di suatu negara dalam suatu periode tertentu adalah dengan penggunaan data Produk Domestik Bruto (PDB). PDB pada dasarnya merupakan jumlah nilai tambah yang dihasilkan oleh seluruh unit usaha dalam suatu negara tertentu, atau merupakan jumlah nilai barang dan jasa akhir yang dihasilkan oleh seluruh unit ekonomi.

PDB atas dasar harga berlaku menggambarkan nilai tambah barang dan jasa yang dihitung menggunakan harga yang berlaku pada setiap tahun, sedangkan PDB atas dasar harga konstan menunjukkan nilai tambah barang dan jasa tersebut yang dihitung menggunakan harga yang berlaku pada satu tahun tertentu sebagai dasar. PDB atas dasar harga berlaku dapat digunakan untuk melihat pergeseran dan struktur ekonomi, sedang harga konstan digunakan untuk mengetahui pertumbuhan ekonomi dari tahun ke tahun.

\section{Suku Bunga Bank Indonesia (BI Rate)}

BI Rate adalah suku bunga kebijakan yang mencerminkan sikap atau stance kebijakan moneter yang ditetapkan oleh bank Indonesia dan diumumkan kepada publik. BI Rate diumumkan oleh Dewan Gubernur Bank Indonesia setiap Rapat Dewan Gubernur bulanan dan diimplementasikan pada operasi moneter yang dilakukan Bank Indonesia melalui pengelolaan likuiditas (liquidity management) di pasar uang untuk mencapai sasaran operasional kebijakan moneter. Suku bunga acuan Bank Indonesia terdiri dari 2 komponen utama yaitu deposit facility rate dan lending facility rate pada setiap penetapannya

\section{Perbankan}

Menurut Undang-undang No. 10 Tahun 1998 tentang Perbankan, bank adalah badan usaha yang menghimpun dana dari masyarakat dalam bentuk simpanan dan menyalurkannya kepada masyarakat dalam bentuk kredit dan atau bentuk-bentuk lainnya dalam rangka meningkatkan taraf hidup masyarakat. Jasa yang di berikan perbankan bersifat umum, artinya dapat memberikan seluruh jasa perbankan yang ada sesuai ketentuan jenis perbankannya.

Dari segi fungsinya, bank terdiri dari 2 macam yaitu :

1. Bank Umum

Bank yang melaksanakan kegiatan usaha secara konvensional dan atau berdasarkan prinsip syariah, yang dalam kegiatannya memberikan jasa 
dalam lalu lintas pembayaran;

2. Bank Perkreditan Rakyat

Bank yang melaksanakan kegiatan usaha secara konvensional atau berdasarkan prinsip syariah, yang dalam kegiatannya tidak memberikan jasa dalam lalu lintas pembayaran.

\section{Perkreditan}

Berdasarkan pandangan hukum perbankan yang diatur dalam pasal 1 ayat 11 UU Perbankan No. 10 tahun 1998, disebutkan bahwa kredit adalah penyediaan uang atau tagihan yang dapat dipersamakan dengan itu, berdasarkan persetujuan atau kesepakatan pinjam - meminjam antara bank dengan pihak lain yang mewajibkan pihak peminjam untuk melunasi utangnya setelah jangka waktu tertentu dengan pemberian bunga.

Adapun definisi untuk kredit konsumsi, modal kerja dan investasi sesuai dengan Laporan Bank Umum (LBU) adalah sebagai berikut:

1. Kredit konsumsi adalah pemberian kredit untuk keperluan konsumsi dengan cara membeli, menyewa atau dengan cara lain. Misalnya: Kredit Kendaraan Bermotor, (KKB), Kredit Multiguna, Kredit Pegawai dan Pensiunan, Kredit Pemilikan Rumah (KPR) dan Kredit Pemilikan Apartemen (KPA);

2. Kredit modal kerja adalah kredit jangka pendek yang diberikan untuk membiayai keperluan modal kerja debitur;

3. Kredit investasi adalah kredit jangka menengah/panjang untuk pembelian barang-barang modal dan jasa yang diperlukan guna rehabilitasi, modernisasi, ekspansi dan relokasi proyek dan atau pendirian usaha baru.

Kriteria penilaian yang harus dilakukan oleh bank untuk mendapatkan nasabah yang benar-benar menguntungkan salah satunya dilakukan dengan analisis 5C dan 7P. Kegiatan pemberian kredit dalam praktek perbankan (Kasmir, 2014) dengan melakukan analisis dengan 5C, terdiri dari:

1. Character (Watak);

2. Capacity (Kemampuan);

3. Capital (modal);

4. Collateral (Jaminan atau agunan);

5. Condition of Economy (Kondisi Perekonomian).

Selain memperhatikan hal-hal di atas, bank harus pula mengetahui mengenai tujuan penggunaan kredit dan rencana pengembangan kreditnya. Bank dalam memberikan kredit, selain menerapkan prinsip 5C, juga menerapkan prinsip 7P, antara lain:

1. Personality;

2. Party (Para Pihak);

3. Purpose (Tujuan);

4. Payment (Pembayaran);

5. Profitability (Perolehan Laba);

6. Protection (Perlindungan);

7. Prospect.

\section{Hubungan Kredit Perbankan, BI Rate dan Pertumbuhan Ekonomi}


Dalam rangka pembiayaan kegiatan perekonomian untuk mendorong pertumbuhan ekonomi yang cukup tinggi, pemberian kredit perbankan mempunyai peranan penting. Peranan kredit perbankan di dalam mendorong pertumbuhan ekonomi dapat berarti penciptaan lapangan kerja, baik melalui perluasan produksi dan kegiatan usaha lainnya maupun melalui pengaruhnya dalam mendorong munculnya unit-unit usaha baru. Selain itu, kredit perbankan dapat diarahkan untuk pemerataan kesempatan berusaha yang antara lain melalui alokasi pemberian kredit menurut prioritas pembangunan dan golongan ekonomi sehingga pada gilirannya dapat memperluas pemerataan hasil-hasil pembangunan.

Bank Indonesia selaku pengambil kebijakan moneter bertugas untuk mengatur laju inflasi, jumlah uang beredar serta menggunakan instrumen BI Rate yang dijadikan acuan suku bunga kredit yang ditetapkan bank. Dengan adanya pelonggaran kebijakan moneter dalam hal ini penurunan BI Rate diharapkan dapat menurunkan suku bunga kredit investasi, kredit modal kerja, dan kredit konsumsi sehingga lebih menarik para pelaku industri di masing-masing sektor ekonomi untuk melakukan pinjaman/kredit terkait pembiayaan dalam rangka memajukan pertumbuhan usahanya yang nantinya akan bermuara pada tumbuhnya perekonomian dari sisi makro.

\section{Penelitian terdahulu}

Penelitian yang dilakukan oleh Sarah Farahdiba (2011) tentangPengaruh Kredit Perbankan Terhadap Pertumbuhan Ekonomi Periode Tahun 2005-2009 di Beberapa Daerah di Indonesia.Hasil penelitian menyatakan bahwakredit investasi dan kredit modal kerja berpengaruh positif terhadap pertumbuhan ekonomi, namun kredit konsumsi berpengaruh negatif terhadap pertumbuhan ekonomi.

Penelitian lain dilakukan Rafika Sari (2006) dengan judul Pengaruh Perkembangan Perbankan terhadap Pertumbuhan Ekonomi Regional di Indonesia Periode Tahun 1987-2002. Hasil penelitian menyatakan bahwa seluruh variabel pembentuk pertumbuhan ekonomi menunjukkan hubungan yang positif terhadap pertumbuhan ekonomi, yaitu kontribusi sumber daya alam, angkatan kerja, potensi keuangan daerah (penerimaan pajak, bagi hasil dan retribusi), desentralisasi, tingkat upah dan tingkat keterbukaan daerah (jumlah ekspor dan impor). Hasil estimasi juga menunjukkan bahwa dengan asumsi $\mathrm{a}=$ 0,1 seluruh indikator perbankan secara signifikan mempengaruhi pertumbuhan ekonomi, sedangkan dengan asumsi $a=0,05$, hanya ada dua indikator perbankan bervariasi secara signifikan mempengaruhi pertumbuhan ekonomi yaitu aset perbankan dan kredit perbankan. Indikator dana yang dihimpun oleh perbankan menunjukkan hasil yang tidak signifikan mempengaruhi pertumbuhan ekonomi.

Selanjutnya penelitian yang dilakukan oleh Harmanta (2005) dengan judul Disintermediasi Fungsi Perbankan di Indonesia Pasca Krisis 1997. Hasil analisis menunjukkan bahwa Produk Domestik Bruto (PDB) memiliki hubungan yang searah (positif) dan signifikan terhadap permintaan kredit, yang berarti bahwa meningkatnya pertumbuhan ekonomi akan meningkatkan permintaan kredit, dan sebaliknya dalam kondisi perekonomian yang melemah (resesi) maka 
permintaan kredit cenderung menurun.

Penelitian berikutnya dilakukan Inggrid (2006) dengan judul Sektor Keuangan dan Pertumbuhan Ekonomi di Indonesia: Pendekatan Kausalitas dalam Multivariate Vector Error Correction Model (VECM). Penelitian ini membuktikan adanya hubungan kointegrasi dan kausalitas (dua arah) antara kredit perbankan dan pertumbuhan ekonomi di Indonesia. Dalam penelitian ini juga dijelaskan pertumbuhan ekonomi yang di-proxy dengan produk domestik bruto sedangkan perkembangan sektor keuangan menggunakan dua proxy yang salah satunya adalah kredit perbankan

\section{Kerangka Pemikiran}

Mengingat peranan kredit perbankan sedemikian penting dalam perekonomian Indonesia dan juga memerhatikan hubungan antara kredit yang disalurkan perbankan terhadap pertumbuhan ekonomi yang ingin dicapai sekaligus mempertimbangkan keragaman faktor-faktor yang memiliki dampak terhadap dinamika pertumbuhan ekonomi nasional sebagaimana yang sudah djelaskan sebelumnya, maka penulis bermaksud melakukan penelitian dengan berfokus pada perkembangan kredit sektoral dengan melihat dari sisi agregat kredit sektoral yang disalurkan oleh perbankan dan juga pengaruh BI Rate dalam mempengaruhi tingkat pertumbuhan ekonomi nasional dengan melihat dari sisi total agregat PDB setiap tahun dengan periode dimulai dari tahun 2011 sampai tahun 2015.

Berdasarkan uraian diatas, maka penulis menyimpulkan kerangka konseptual dari penelitian ini sebagai berikut :

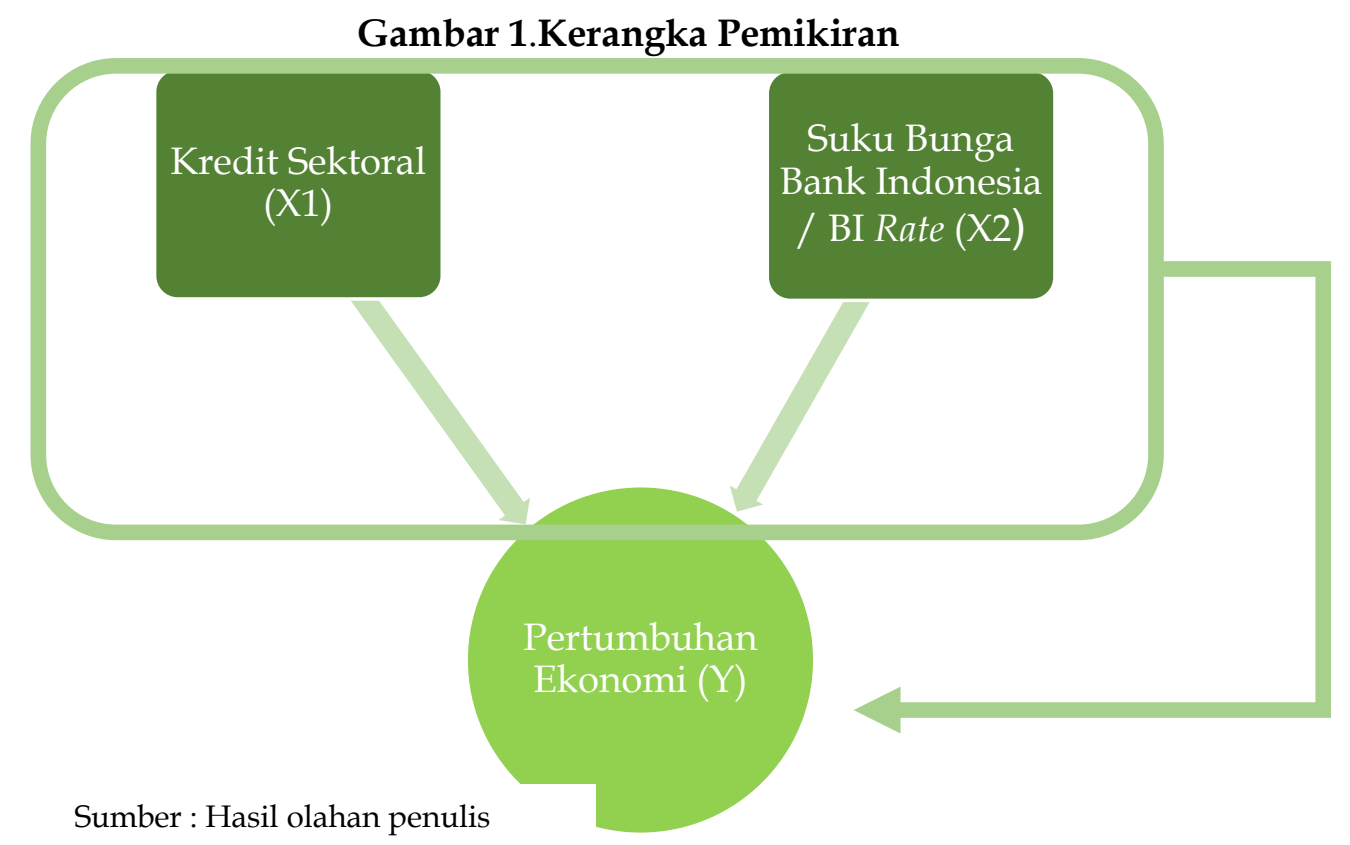

Keterangan :

Variabel Independen :

1. Kredit Sektoral (X1) 
Variabel Dependen :

1. Pertumbuhan Ekonomi (Y)

\section{Pengembangan Hipotesis}

H1 : Pertumbuhan kredit sektoral secara parsial berpengaruh terhadap pertumbuhan ekonomi dan memiliki hubungan positif (searah).

H2 : BI Rate secara parsial berpengaruh terhadap pertumbuhan ekonomi dan memiliki hubungan negatif (tidak searah).

H3 : Pertumbuhan kredit sektoral dan BI Rate secara bersama berpengaruh terhadap pertumbuhan ekonomi.

\section{METODE}

\section{Jenis Penelitian}

Jenis penelitian ini adalah penelitian kuantitatif. Penelitian kuantitatif menekankan pada pengujian data melalui pengukuran variabel penelitian dengan angka dan melakukan analisis data melalui prosedur statistik. Adapun yang yang diteliti dalam penelitian ini adalah bagaimana peranan kredit sektoral yang terdiri dari kredit investasi dan kredit modal kerja serta pengaruh BI Rate terhadap variabel dependen yaitu pertumbuhan ekonomi nasional. Khusus peranan kredit sektoral dilihat dari sisi dampak keseluruhan secara langsung dan seketika dari seluruh sektor selama periode observasi.

\section{Populasi dan Sampel}

Populasi dan sampel pada penelitian ini adalah sektor-sektor ekonomi atau lapangan usaha.Sektor-sektor ekonomi menurut kelompok sektor pada PDB yang berdasarkan pada Klasifikasi Baku lapangan Usaha Indonesia (KLBI) tahun 2009 dan tahun 2015 terdiri dari 17 sektor. Sementara kelompok sektor/lapangan usaha yang terdapat penyaluran kredit perbankanberdasarkan KLBI tahun 2005 tahun 2005 terbagi menjadi 18 sektor / lapangan usaha berdasarkan kredit sektoral yang disalurkan oleh bank umum sementara untuk kredit sektoral yang disalurkan oleh bank perkreditan rakyat pada lapangan usaha terbagi menjadi 17 sektor (perbedaan klasifikasi sektor-sektor ekonomi ini dapat dilihat pada tabel 2).

Oleh karena terdapat perbedaan jumlah sektor/lapangan usaha antara kredit yang disalurkan oleh bank umum dan bank perkreditan rakyat, maka penulis melakukan identifikasi terlebih dahulu terhadap sektor-sektor yang memiliki kesamaan. Kemudian dengan melihat adanya perbedaan pada sektor badan internasional dan badan ekstra internasional lainnya (pada penyaluran kredit bank umum) serta sektor kegiatan usaha yang belum jelas batasannya (penyaluran kredit bank umum dan bank perkreditan rakyat) serta dengan mendasarkan pada fokus penelitian ini yang ingin melihat peranan sekaligus dampak keseluruhan kredit sektoral terhadap total agregat PDB maka dipilih 16 sektor dari klasifikasi sektor-sektor yang disalurkan kredit perbankan sebagai data cross section-nya. Adapun data time series-nya sebagai periode observasi 
dimulai dari tahun 2011-2015. Mengingat data panel merupakan kombinasi data cross section dan data time series maka jumlah data observasi menjadi sebanyak 80 .

Tabel 2. Perbedaan Klasifikasi Sektor-Sektor Ekonomi / Lapangan Usaha

\section{a. Klasifikasi Sektor pada PDB}

\begin{tabular}{|c|c|c|c|c|c|c|}
\hline LAPANGAN USAHA & 2010 & 2011 & 2012 & 2013 & 2014 & 2015 \\
\hline Pertanian, Kehutanan, dan Perikanan & $956.119,7$ & $993.857,3$ & $1.039 .440,7$ & $1.083 .141,8$ & $1.129 .052,7$ & $1.174 .456,8$ \\
\hline Pertambangan dan Penggalian & $718.128,6$ & $748.956,3$ & $771.561,6$ & $791.054,4$ & $796.711,6$ & $756.239,2$ \\
\hline Industri Pengolahan & $1.512 .760,8$ & $1.607 .452,0$ & $1.697 .787,2$ & $1.771 .961,9$ & $1.853 .688,2$ & $1.932 .457,4$ \\
\hline Pengadaan Listrik dan Gas & $72.549,1$ & $76.678,1$ & $84.393,0$ & $88.805,1$ & $93.755,9$ & $94.894,8$ \\
\hline Pengadaan Air, Pengelolaan Sampah, Limbah dan & $5.848,5$ & $6.125,1$ & $6.329,8$ & $6.539,9$ & $6.923,5$ & $7.420,2$ \\
\hline Konstruksi & $626.905,4$ & $683.421,9$ & $728.226,4$ & $772.719,6$ & $826.615,6$ & $881.583,9$ \\
\hline Perdagangan Besar dan Eceran; Reparasi Mobil dan & $923.923,8$ & $1.013 .199,6$ & $1.067 .911,5$ & $1.119 .272,1$ & $1.177 .048,6$ & $1.206 .074,7$ \\
\hline Transportasi dan Pergudangan & $245.375,4$ & $265.774,0$ & $284.662,6$ & $304.506,2$ & $326.933,0$ & $348.775,6$ \\
\hline Penvediaan Akomodasi dan Makan Minum & $200.281,8$ & $214.022,0$ & $228.232,6$ & $243.748,3$ & $257.815,5$ & $269.054,5$ \\
\hline Informasi dan Komunikasi & $256.048,1$ & $281.693,8$ & $316.278,7$ & $349.150,1$ & $384.407,4$ & $423.063,5$ \\
\hline Jasa Keuangan dan Asuransi & $239.728,4$ & $256.443,0$ & $280.896,1$ & $305.515,1$ & $319.825,5$ & $347.095,7$ \\
\hline Real Estate & $198.213,5$ & $213.441,4$ & $229.254,2$ & $244.237,5$ & $256.440,2$ & $268.811,4$ \\
\hline Jasa Perusahaan & $99.085,4$ & $108.239,3$ & $116.293,3$ & $125.490,7$ & $137.795,3$ & $148.395,5$ \\
\hline $\begin{array}{l}\text { Administrasi Pemerintahan, Pertahanan dan Jaminan } \\
\text { Sosial Wajib }\end{array}$ & $259.646,1$ & $276.336,8$ & $282.235,3$ & $289.448,9$ & $296.329,7$ & $310.393,9$ \\
\hline Jasa Pendidikan & $201.559,5$ & $215.029,1$ & $232.704,3$ & $250.016,2$ & $263.889,6$ & $283.540,0$ \\
\hline Jasa Kesehatan dan Kegiatan Sosial & $66.444,7$ & $72.592,1$ & $78.380,1$ & $84.621,4$ & $91.357,1$ & $97.840,8$ \\
\hline Jasa lainnya & $101.061,0$ & $109.372,4$ & $115.675,4$ & $123.083,1$ & $134.070,1$ & $144.902,4$ \\
\hline NILAI TAMBAH BRUTO ATAS HARGA DASAR & $6.683 .679,8$ & $7.142 .634,2$ & $7.560 .262,8$ & $7.953 .312,3$ & $8.352 .659,5$ & $8.695 .000,3$ \\
\hline PAJAK DIKURANG SUBSIDI ATAS PRODUK & $180.453,3$ & $145.001,1$ & $166.820,6$ & $203.185,5$ & $213.611,7$ & $281.931,2$ \\
\hline PRODUK DOMESTIK BRUTO & $6.864 .133,1$ & $7.287 .635,3$ & $7.727 .083,4$ & $8.156 .497,8$ & $8.566 .271,2$ & $8.976 .931,5$ \\
\hline
\end{tabular}

Sumber : Badan Pusat Statistik dan CEIC, Data Diolah dengan MS. Excel 2016

\section{b. Klasifikasi Sektor pada Kredit yang Disalurkan Bank Umum}




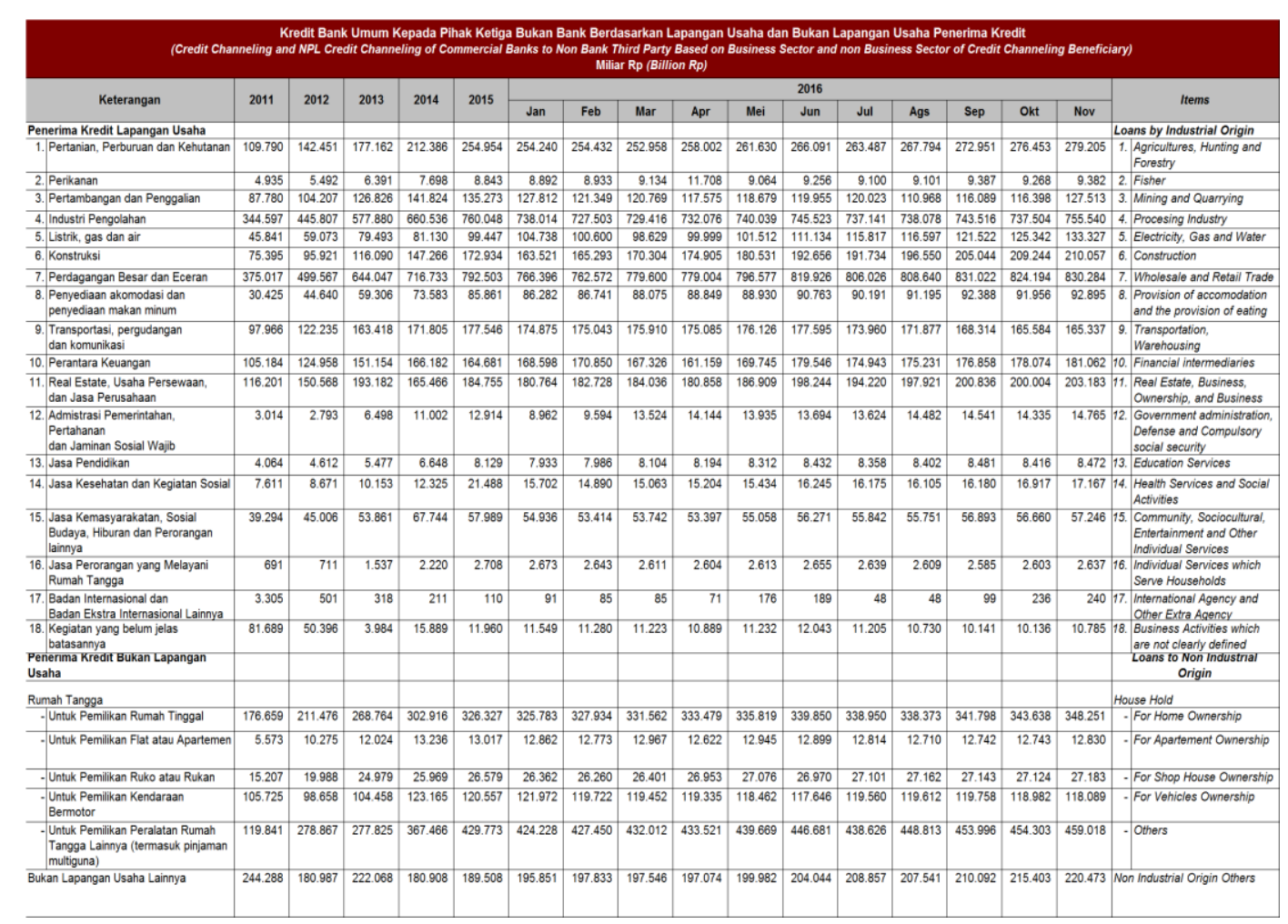

Sumber : Statistik Perbankan Indonesia-OJK, diolah

c. Klasifikasi Sektor pada Kredit yang BPR 


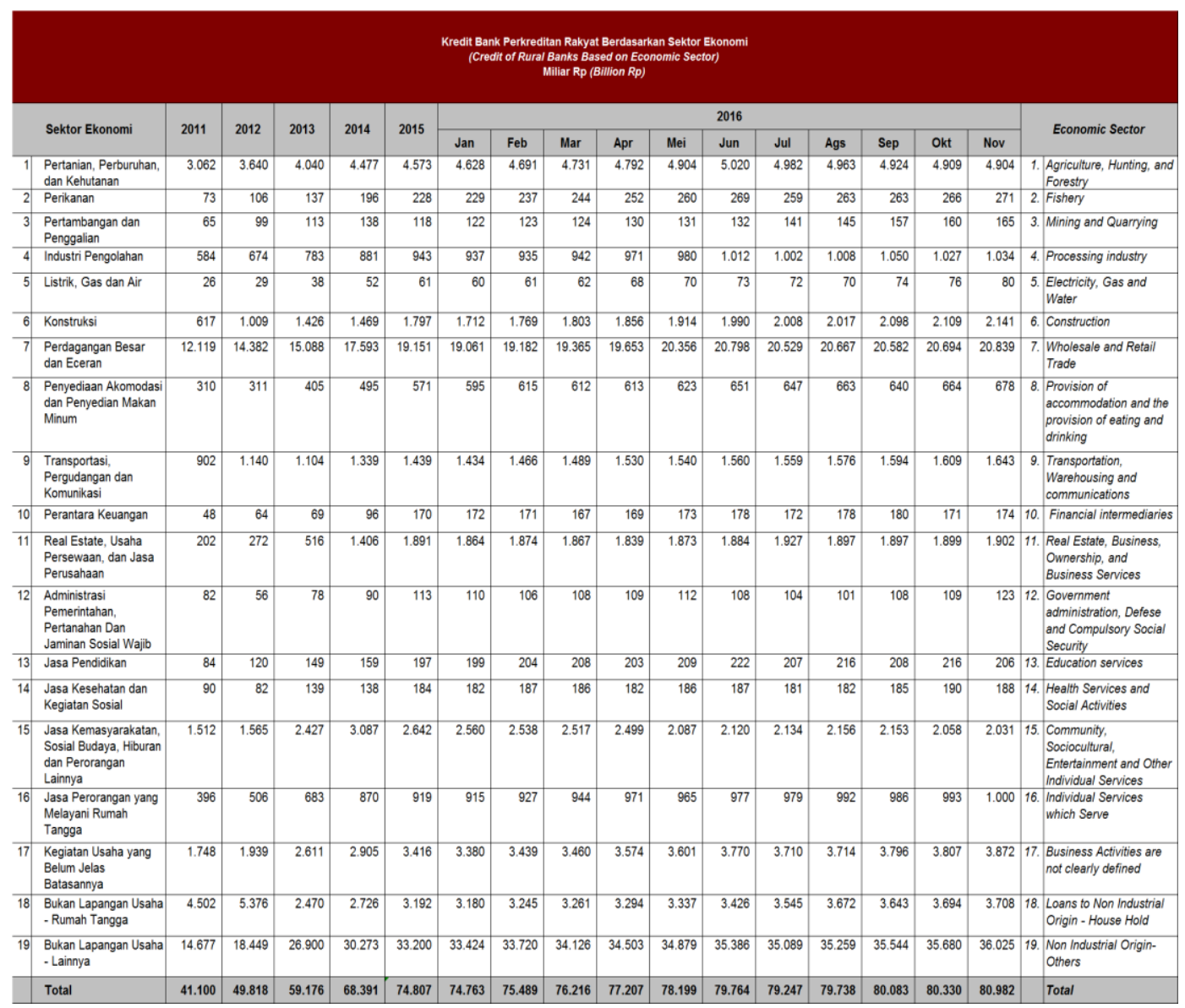

Sumber : Statistik Perbankan Indonesia, OJK

\section{Pengumpulan Data}

Data yang digunakan adalah data sekunder yang bersumber dari :

1. Data terkait kredit per sektor: Statistik Perbankan Indonesia (SPI) yang dipublikasikan oleh Otoritas Jasa Keuangan (OJK);

2. BI Rate melalui website Bank Indonesia;

3. PDB diperoleh melalui laporan realisasi PDB yang dipublikasikan oleh Badan Pusat Statistik (BPS);

4. CEIC : Program penyedia data ekonomi dan keuangan dari seluruh negara yang banyak digunakan oleh para pengambil kebijakan, ekonom, analis, investor, perusahaan, perguruan tinggi, dan pihak lainnya di seluruh dunia. Data PDB, kredit sektoral, dan BI Rate yang diunduh dari CEIC adalah data valid yang bersumber dari BI, OJK, dan BPS.

\section{Metode Analisis}

Metode analisis data yang digunakan dalam penelitian ini adalah regresi data panel (panel data) dengan model persamaan tunggal berganda dengan alat analisis yang dipakai adalah Program Eviews 9 menggunakan metode fixed effect. Analisis dimulai dari penyajian data total agregat PDB tahunan, data penyaluran kredit sektoral pada 16 sektor/lapangan usaha serta rata-rata BI Rate tahunan selama periode 2011-2015 yang kemudian data PDB tahunan dan kredit sectoral 
ini ditransformasi dalam bentuk logaritma natural $(\log )$ dengan menggunakan eviews 9, adapun data BI Rate tidak dilakukan transformasi dalam bentuk logkarena beberapa data indikator makroekonomi seperti suku bunga dalam hal ini BI Rate demi tujuan analisis/estimasi model ekonomi maka tidak perlu ditransformasi ke logaritma natural (Mahyus Ekananda, 2015).

Analisis data diawali dengan melakukan estimasi statistik deskriptif dan uji normalitas data. Kemudian dihitung dampak kredit sektoral, BI Rate terhadap PDB dengan menggunakan model terpilih fixed effect method setelah sebelumnya terlebih dahulu dilakukan tiga macam uji mulai dari Uji Chow, Uji Hausman dan Uji Langrange Multiplier. Setelah itu dilakukan uji asumsi klasik terhadap model terpilih ini mulai dari Uji Multikolinieritas, Uji Heteroskedastisitas, dan Uji Normalitas Regresi. Uji kelayakan (Goodness of Fit) model regresi data panel juga dilakukan yang diawali uji hipotesis yang terdiri dari Uji-t untuk melihat pengaruh variabel independen secara parsial terhadap variabel dependen serta Uji-F yang dipakai untuk melihat pengaruh variabel independen secara simultan terhadap variabel dependenpada penelitian ini. Kemudian untuk melihat kelayakan model yang digunakan dengan melihat koefisien determinasi pada Adjusted R-Squared (Mahyus Ekananda, 2015) pada metode fixed effect yang terpilih.

Persamaan model yang digunakan adalah :

$$
\log \left(\mathrm{PDB}_{\mathrm{it}}\right)=\beta_{0 \mathrm{i}}+\boldsymbol{\beta}_{\mathbf{1}} \log (\text { Kredit Sektoralit })+\boldsymbol{\beta}_{\mathbf{2}}\left(\mathrm{BIRate}_{\mathbf{i t}}\right)+\varepsilon_{\mathbf{i t}}
$$

\section{Definisi dan Ukuran Variabel}

Variabel-variabel yang digunakan pada penelitian ini sebagai berikut:

\section{Pertumbuhan Ekonomi yang di-proxy-kan dengan Pertumbuhan PDB}

PDB adalah jumlah nilai tambah yang dihasilkan oleh seluruh unit usaha dalam suatu negara tertentu, atau merupakan jumlah nilai barang dan jasa akhir yang dihasilkan oleh seluruh unit ekonomi. Perhitungan tingkat pertumbuhan ekonomi dengan melihat perubahan total agregat PDB tahunan pada suatu tahun dengan tahun sebelumnya dan atau secara rumus sebagai berikut:

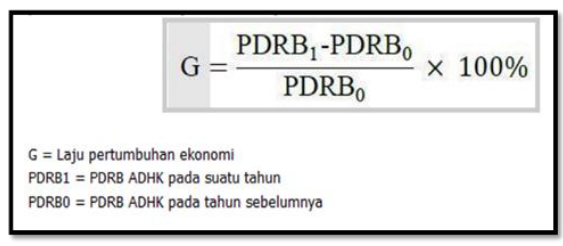

\section{Suku Bunga Acuan Bank Indonesia (BI Rate)}

BI Rate adalah suku bunga kebijakan yang mencerminkan sikap atau stance kebijakan moneter yang ditetapkan oleh Dewan Gubernur Bank Indonesia setiap Rapat Dewan Gubernur bulanan dan diumumkan kepada publik. BI Ratesecara konsisten dan bertahap dalam kelipatan 25 basis poin (bps). Dalam kondisi untuk menunjukkan intensi Bank Indonesia yang lebih besar terhadap pencapaian sasaran inflasi, maka perubahan BI Rate dapat dilakukan lebih dari 25 bps dalam kelipatan 25 bps. 


\section{Kredit Sektoral/Lapangan Usaha}

Penyaluran kredit pada 16 sektor-sektor ekonomi ini merupakan merupakan agregat dari kredit modal kerja dan kredit investasi yang disalurkan oleh bank umum dan bank perkreditan rakyat. Data agregat kredit sektoral yang digunakan pada penelitian ini merupakan hasil perhitungan total kredit yang disalurkan oleh bank umum dan juga bank perkreditan rakyat (lihat tabel 3).

Tabel 3. Total Kredit per Sektor / Lapangan Usaha yang Disalurkan Bank Umum dan BPR (Miliar Rupiah)

\begin{tabular}{|c|c|c|c|c|c|}
\hline \multicolumn{6}{|c|}{$\begin{array}{l}\text { Total Kredit per Sektor/Lapangan Usaha yang Disalurkan Bank Umum dan BPR } \\
\text { (Miliar Rupiah) }\end{array}$} \\
\hline Keterangan & 2011 & 2012 & 2013 & 2014 & 2015 \\
\hline \multicolumn{6}{|c|}{ Penerima Kredit Lapangan Usaha } \\
\hline 1. Pertanian, Perburuan dan Kehutanan & 112,852 & 146,091 & 181,202 & 216,863 & 259,527 \\
\hline 2. Perikanan & 5,008 & 5,599 & 6,528 & 7,895 & 9,071 \\
\hline 3. Pertambangan dan Penggalian & 87,845 & 104,307 & 126,939 & 141,962 & 135,391 \\
\hline 4. Industri Pengolahan & 345,181 & 446,482 & 578,663 & 661,418 & 760,991 \\
\hline 5. Listrik, gas dan air & 45,867 & 59,102 & 79,532 & 81,182 & 99,508 \\
\hline 6. Konstruksi & 76,012 & 96,930 & 117,516 & 148,735 & 174,732 \\
\hline 7. Perdagangan Besar dan Eceran & 387,136 & 513,949 & 659,135 & 734,326 & 811,654 \\
\hline $\begin{array}{l}\text { 8. Penyediaan akomodasi dan penyediaan } \\
\text { makan minum }\end{array}$ & 30,735 & 44,951 & 59,711 & 74,078 & 86,432 \\
\hline $\begin{array}{l}\text { 9. Transportasi, pergudangan } \\
\text { dan komunikasi }\end{array}$ & 98,867 & 123,374 & 164,523 & 173,144 & 178,985 \\
\hline 10. Perantara Keuangan & 105,233 & 125,022 & 151,223 & 166,278 & 164,852 \\
\hline $\begin{array}{l}\text { 11. Real Estate, Usaha Persewaan, } \\
\text { dan Jasa Perusahaan }\end{array}$ & 116,403 & 150,840 & 193,698 & 166,872 & 186,646 \\
\hline $\begin{array}{l}\text { 12. Admistrasi Pemerintahan, Pertahanan } \\
\text { dan Jaminan Sosial Wajib }\end{array}$ & 3,097 & 2,848 & 6,577 & 11,092 & 13,027 \\
\hline 13. Jasa Pendidikan & 4,148 & 4,732 & 5,626 & 6,807 & 8,325 \\
\hline 14. Jasa Kesehatan dan Kegiatan Sosial & 7,702 & 8,753 & 10,292 & 12,463 & 21,672 \\
\hline $\begin{array}{l}\text { 15. Jasa Kemasyarakatan, Sosial Budaya, } \\
\text { Hiburan dan Perorangan lainnya }\end{array}$ & 40,806 & 46,571 & 56,288 & 70,831 & 60,631 \\
\hline $\begin{array}{l}\text { 16. Jasa Perorangan yang Melayani } \\
\text { Rumah Tangga }\end{array}$ & 1,087 & 1,217 & 2,220 & 3,090 & 3,627 \\
\hline
\end{tabular}

Sumber : Otoritas Jasa Keuangan, data diolah

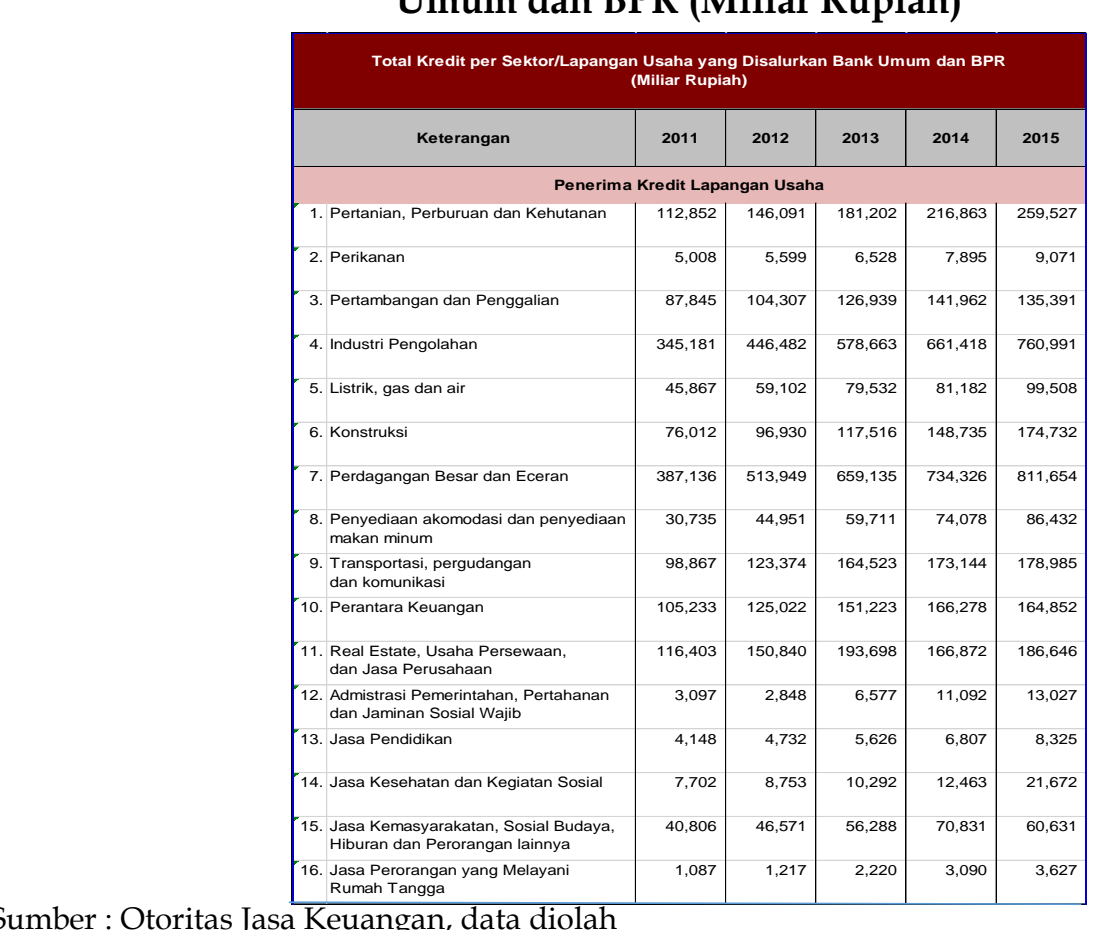

Catatan : Sektor perantara keuangan pada data ini adalah non-perbankan

\section{HASIL DAN PEMBAHASAN}

\section{Hasil Estimasi Menggunakan Metode Fixed Effect}

Untuk mengetahui dampak dari kredit sektoral dan BI Rate terhadap total agregat PDB maka digunakanmetode fixed effectsebagai model yang terpilih serta juga dengan mempertimbangkan MetodeRule of Thumb (Damodar Gujarati, 2012) dan penjelasan terkait data panel panjang dan data panel pendek (Mahyus Ekananda, 2014) yang menyatakan bahwa jika $\mathrm{N}$ (data cross section) besar dan $\mathrm{T}$ kecil (data time series) sementara diyakini bahwa $\mathrm{N}$ yang dipilih dalam penelitian tidak diambil secara acak maka metode fixed effect harus digunakan.

Sebagaimana dapat dilihat pada tabel 4 bahwa Adjusted R-squared bernilai 0.789363 yang berarti bahwa model ini mengestimasi variabel-variabel independen memiliki pengaruh pada variabel dependen sebesar 78,94 persen sementara 21,06 persen lainnya dijelaskan oleh variabel-variabel lain yang tidak diestimasi dalam model ini. 
Pada tabel 4 juga dapat dilihat bahwa secara keseluruhan, variabel-variabel kredit sektoral dan BI Rate pada model ini mempengaruhi variabel dependen (PDB/pertumbuhan ekonomi) secara positif. Selain itu, p-value dari C (konstanta) tersebut adalah sebesar 0.0000 yang berarti bahwa variabel-variabel independen pada model secara keseluruhan berpengaruh secara signifikan.

Apabila diamati tiap variabel independennya maka untuk variabel kredit sektoral berpengaruh positif sebesar 0.168633 dengan p-value sebesar 0.0000 , artinya setiap kenaikan 1 persen pada kredit sektoral ceteris paribus akan meningkatkan 0,17 persen nilai PDB dan berpengaruh secara signifikan. Kemudian untuk variabel BI Rate berpengaruh positif sebesar 0.027573 dengan $p$ value sebesar 0.0007, artinya setiap kenaikan 1 persen pada BI Rateceteris paribus akan meningkatkan 0.03 persen nilai PDB dan juga berpengaruh secara signifikan. Adapun persamaan regresi dari hasil estimasi fixed effect model tersebut adalah sebagai berikut:

LOGPDB $=13.8918430154+0.16863263202 *$ LOGKREDIT $+0.0275733770434 *$ BI_RATE $+\mathrm{e}$

Tabel 4. Hasil Estimasi Fixed Effect Model

Dependent Variable: LOGPDB

Method: Panel Least Squares

Date: 02/14/17 Time: 15:49

Sample: 20112015

Periods included: 5

Cross-sections included: 16

Total panel (balanced) observations: 80

\begin{tabular}{|c|c|c|c|c|}
\hline Variable & Coefficient & Std. Error & t-Statistic & Prob. \\
\hline $\mathrm{C}$ & 13.89184 & 0.148283 & 93.68495 & 0.0000 \\
\hline LOGKREDIT & 0.168633 & 0.016463 & 10.24282 & 0.0000 \\
\hline BI_RATE & 0.027573 & 0.007697 & 3.582368 & 0.0007 \\
\hline \multicolumn{5}{|c|}{ Effects Specification } \\
\hline \multicolumn{5}{|c|}{ Cross-section fixed (dummy variables) } \\
\hline R-squared & 0.834690 & \multicolumn{2}{|c|}{ Mean dependent var } & 15.90995 \\
\hline Adjusted R-squared & 0.789363 & \multicolumn{2}{|c|}{ S.D. dependent var } & 0.074092 \\
\hline S.E. of regression & 0.034005 & \multicolumn{2}{|c|}{ Akaike info criterion } & -3.729534 \\
\hline Sum squared resid & 0.071691 & \multicolumn{2}{|c|}{ Schwarz criterion } & -3.193578 \\
\hline Log likelihood & 167.1814 & \multicolumn{2}{|c|}{ Hannan-Quinn criter. } & -3.514654 \\
\hline F-statistic & 18.41489 & \multicolumn{2}{|c|}{ Durbin-Watson stat } & 1.542303 \\
\hline Prob(F-statistic) & 0.000000 & & & \\
\hline
\end{tabular}

Sumber: Data diolah dengan Eviews 9

\section{Pengujian Hipotesis}

Masing-masing data variabel independen yang telah diestimasi pengaruhnya terhadap variabel dependen kemudian akan dilakukan pengujian hipotesis baik secara parsial ataupun simultan. Data tersebut yaitu kredit sektoral (X1)dan BI Rate (X2) terhadap pertumbuhan ekonomi yang di-proxy 
dengan total agregat PDB tahunan(Y). Uji normalitas data telah dilakukan dengan menggunakan program Eviews 9 dan hasil uji menyatakan data tersebut telah berdistribusi normal (lihat tabel 5). Data yang akan diuji hipotesis ini juga telah melalui uji asumsi klasik mulai dari uji multikolinieritas, uji heteroskedastisitas, dan uji normalitas regresi (lihat tabel 6).

\begin{tabular}{|l|ccc|}
\hline & LOGPDB & LOGKREDIT & BI_RATE \\
\cline { 2 - 4 } Mean & 15.90995 & 10.85903 & 6.779167 \\
Median & 15.91433 & 11.37522 & 6.583333 \\
Maximum & 16.01017 & 13.60683 & 7.541667 \\
Minimum & 15.80169 & 6.990884 & 5.770833 \\
Std. Dev. & 0.074092 & 1.702829 & 0.679026 \\
Skewness & -0.116804 & -0.482918 & -0.135682 \\
Kurtosis & 1.718301 & 2.212620 & 1.624559 \\
& & & \\
Jarque-Bera & 5.657750 & 5.176017 & 6.551586 \\
Probability & 0.059079 & 0.075170 & 0.037787 \\
Sum & 1272.796 & 868.7221 & 542.3333 \\
Sum Sq. Dev. & 0.433679 & 229.0704 & 36.42500 \\
Observations & & & \\
& & & \\
\hline
\end{tabular}

Sumber: Data diolah dengan Eviews 9

\section{Tabel 5 Uji Normalitas Data}

- Dalam uji normalitas data ini, tingkat signifikansi $p$-value untuk PDB (Y) tersebut adalah sebesar 0,059079 (lebih besar dari a; 0.05), maka dapat disimpulkan bahwa tingkat signifikansi PDB (Y) yang lebih besar dari nilai a memberikan gambaran bahwa sebaran data tidak terjadi penyimpangan, yang berarti data tersebut berdistribusi normal

a. Uji Normalitas Regresi

\section{Tabel 6 Hasil Uji Asumsi Klasik}

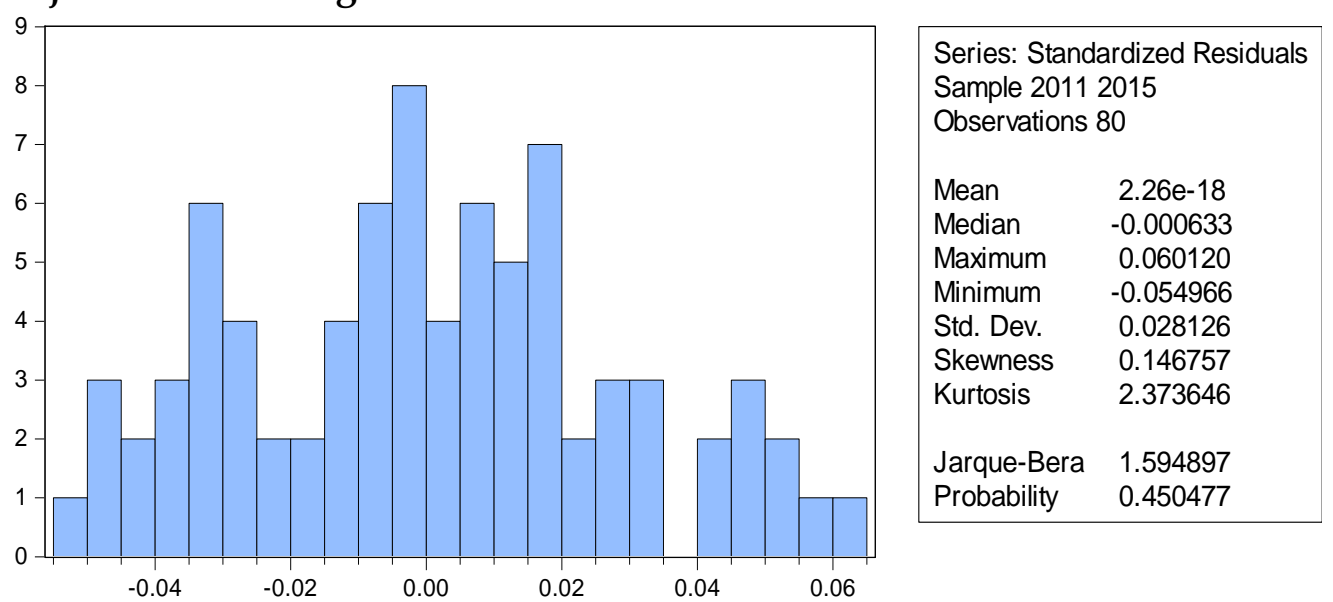

Sumber: Data diolah dengan Eviews 9

- nilai Jarque-Bera adalah sebesar 1.594897 (nilai Jarque-Bera tidak signifikan karena lebih dari kecil 2) dan p-value sebesar 0,450477 yang lebih besar dari nilai signifikansi a $(0,05)$ yang artinya error data berdistribusi normal sehingga 
asumsi normalitas terpenuhi.

b. U

\begin{tabular}{|ccc|}
\hline & LOGKREDIT & BI_RATE \\
\hline LOGKREDIT & 1.000000 & 0.127012 \\
BI_RATE & 0.127012 & 1.000000 \\
\hline
\end{tabular}

tas

Sumber: Data diolah dengan Eviews 9

- Terlihat bahwa hubungan antar variabel independen sebesar 0.127012 yang jauh lebih kecil dari 0,85, sehingga dapat disimpulkan bahwa antara variabel independen tidak terdapat multikolinearitas

\section{c. Uji Heteroskedastisitas}

\section{Output Fixed Effectdengan Pembobotan}

Dependent Variable: LOGPDB

Method: Panel EGLS (Cross-section weights)

Date: 01/27/17 Time: 20:54

Sample: 20112015

Periods included: 5

Cross-sections included: 16

Total panel (balanced) observations: 80

Linear estimation after one-step weighting matrix

\begin{tabular}{ccccc}
\hline \hline Variable & Coefficient & Std. Error & t-Statistic & Prob. \\
\hline \hline C & 13.60378 & 0.097483 & 139.5497 & 0.0000 \\
LOGKREDIT & 0.201284 & 0.010819 & 18.60390 & 0.0000 \\
BI_RATE & 0.017765 & 0.004964 & 3.578967 & 0.0007 \\
\hline \hline
\end{tabular}

Effects Specification

Cross-section fixed (dummy variables)

\begin{tabular}{|c|c|c|}
\hline \multicolumn{3}{|c|}{ Weighted Statistics } \\
\hline R-squared & Mean dependent var & 21.06112 \\
\hline Adjusted R-squared & 0.913849 SiD. dependent var & 9.855722 \\
\hline S.E. of regression & 0.031748 Sum squared resid & 0.062493 \\
\hline F-statistic & 50.29398 Durbin-Watson stat & 1.412830 \\
\hline Prob(F-statistic) & 0.000000 & \\
\hline \multicolumn{3}{|c|}{ Unweighted Statistics } \\
\hline R-squared & 0.824174 Mean dependent var & 15.90995 \\
\hline Sum squared resid & 0.076252 Durbin-Watson stat & 1.347581 \\
\hline
\end{tabular}

Sumber: Data diolah dengan Eviews 9 


\section{Output Fixed Effecttanpa Pembobotan}

Dependent Variable: LOGPDB

Method: Panel Least Squares

Date: 02/14/17 Time: 15:49

Sample: 20112015

Periods included: 5

Cross-sections included: 16

Total panel (balanced) observations: 80

\begin{tabular}{ccccr}
\hline \hline Variable & Coefficient & Std. Error & t-Statistic & Prob. \\
\hline \hline C & 13.89184 & 0.148283 & 93.68495 & 0.0000 \\
LOGKREDIT & 0.168633 & 0.016463 & 10.24282 & 0.0000 \\
BI_RATE & 0.027573 & 0.007 .697 & 3.582368 & 0.0007 \\
\hline \hline
\end{tabular}

Effects Specification

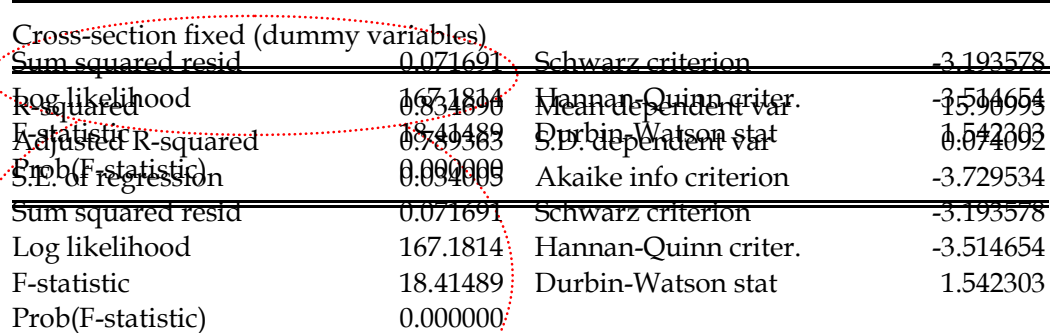

Sumber: Data diolah dengan Eviews 9

\section{Hasil Perbandingan Kedua Model Fixed Effect}

\begin{tabular}{|l|l|l|}
\hline \multicolumn{1}{|c|}{ Parameter } & \multicolumn{1}{c|}{ Fixed Effect Unweighted } & Fixed Effect Weighted \\
\hline Prob. t-Statistic & Ketiganya $<0,05$ & Ketiganya $<0,05$ \\
\hline R-squared & 0,834690 & 0,932388 \\
\hline Prob. (F-Statistic) & 0,00000 & 0,00000 \\
\hline
\end{tabular}

Sumber: Data diolah dengan Eviews 9 dan MS. Excel 2016

- $\quad$ Berdasarkan 3 (tiga) parameter di atas pada dasarnya tidak terdapat perbedaan yang terlalu signifikan, hanya pada $R$-squared saja berbeda antara nilai dari model fixed effect weighted dengan hasil $R$-squared dari model fixed effect unweighted sehingga dapat disimpulkan tidak terjadi heteroskedastisitas pada model fixed effect

\section{Tabel 7. Hasil Uji-F dan Uji-t}

Dependent Variable: LOGPDB

Method: Panel Least Squares

Date: 02/14/17 Time: 15:49

Sample: 20112015

Periods included: 5

Cross-sections included: 16

Total panel (balanced) observations: 80 


\begin{tabular}{crrrr}
\hline \hline Variable & Coefficient & Std. Error & t-Statistic & Prob. \\
\hline \hline C & 13.89184 & 0.148283 & 93.68495 & 0.0000 \\
LOGKREDIT & 0.168633 & 0.016463 & 10.24282 & 0.0000 \\
BI_RATE & 0.027573 & 0.007 .697 & 3.582368 & 0.0007 \\
\hline \hline
\end{tabular}

\begin{tabular}{|c|c|c|c|c|}
\hline \multicolumn{4}{|c|}{ Cross-section fixed (dummy variables) } & \multirow{2}{*}{ Uji-f } \\
\hline R-squared & 0.834690 & Mean dependent var & 15.90995 & \\
\hline Adjusted R-squared & 0.789363 & S.D. dependent var & 0.074092 & \multirow{6}{*}{$\begin{array}{lr}\text { Sumber: } & \text { Data } \\
\text { diolah } & \text { dengan } \\
\text { Eviews } 9 & \end{array}$} \\
\hline S.E. of regression & 0.034005 & Akaike info criterion & -3.729534 & \\
\hline Sum squared resid & 0.071691 & Schwarz criterion & -3.193578 & \\
\hline Eog likely hood & 167.1814 & Hannan-Quinn criter. & -3.514654 & \\
\hline F-statistic & 18.41489 & Durbin-Watson stat & 1.542303 & \\
\hline Prob(F-statistic) & $0: 000000$ & & & \\
\hline
\end{tabular}

\section{Uji Hipotesis Pertama (H1)}

H1 : Pertumbuhan kredit sektoral secara parsial berpengaruh terhadap pertumbuhan ekonomi dan memiliki hubungan positif (searah).

\section{Pembahasan Hasil Uji Hipotesis Pertama}

Dengan asumsi a $<0,05 \mathrm{H}_{\mathrm{o}}$ ditolak dan $\mathrm{H}_{\mathrm{a}}$ diterima yang berarti variabel independen mempunyai pengaruh yang signifikan terhadap variabel dependen, sebaliknya, jika $a>0,05 \mathrm{H}_{\mathrm{o}}$ diterima dan $\mathrm{H}_{\mathrm{a}}$ ditolak, yang berarti bahwa suatu variabel independen tidak mempunyai pengaruh yang signifikan terhadap variabel dependen.

Dari tabel 7 dapat dilihat bahwa koefisien kredit sektoral sebesar 0.168633 yang berarti bahwa setiap kenaikan 1 persen kredit sektoral akan meningkatkan PDB sebesar 0,17 persen. Selain itu, diperoleh $p$-value sebesar 0,0000 $<a=0,05$, maka kita menolak $H_{0}$. Dengan demikian kredit sektoral secara parsial berpengaruh signifikan terhadap PDB dalam mendorong pertumbuhan ekonomi yang berarti sesuai dengan hipotesis pertama.

Hal ini cukup jelas karena pertumbuhan kredit yang meningkat khususnya penyaluran kredit pada sektor-sektor prioritas atau yang berpotensi memberikan daya dorong yang kuat terhadap pertumbuhan PDB tentunya akan semakin mengoptimalkan dan meningkatkan potensi pertumbuhan. Dengan kondisi ini apabila terjadi peningkatan penyaluran kredit pada sektor-sektor ekonomi tersebut akan semakin membuat pelaku dunia usaha semakin bergairah untuk meningkatkan kapasitas produksinya dengan bertambahnya modal yang akhirnya dapat menstimulus pertumbuhan ekonomi. Penyaluran kredit yang berdampak positif ini harus senantiasa ditingkatkan khususnya pada sektorsektor prioritas pemerintah sebagaimana diamanatkan pada program Nawacita seperti : (1) sektor pertanian, (2) sektor maritim, (3) sektor pertambangan dan 
penggalian, (4) sektor konstruksi dalam hal ini kaitannya dengan peningkatan infrastruktur untuk mendorong konektivitas antar daerah di Indonesia yang salah satu tujuannya dapat menekan faktor harga melalui sistem distribusi yang lebih baik dan juga mengurangi kesenjangan wilayah serta dapat menurunkan tingkat income inequality yang semua hal ini tentunya dapat mendorong pertumbuhan ekonomi yang lebih optimal, dan (5) sektor pengolahan (manufaktur) terkait peningakatan daya saing ekspor melalui produk-produk yang berkualitas. Selain itu, tentunya penyaluran kredit pada sektor-sektor lain juga tidak boleh diabaikan tapi tetap memperhatikan potensi masing-masing sektor tersebut dan juga tetap memantau dinamika perekonomian global khususnya pada sektor-sektor yang memiliki posibilitas dampak negatif akan pengaruh perekonomian global yang dapat memberikan dampak shock pada sektor-sektor tersebut secara mikro dan perekonomian nasional secara makro.

\section{Uji Hipotesis Kedua (H2)}

H2 : BI Rate secara parsial berpengaruh terhadap pertumbuhan ekonomi dan memiliki hubungan negatif (tidak searah).

\section{Pembahasan Hasil Uji Hipotesis Kedua}

Dengan asumsi $a<0,05 \mathrm{H}_{\mathrm{o}}$ ditolak dan $\mathrm{H}_{\mathrm{a}}$ diterima yang berarti variabel independen mempunyai pengaruh yang signifikan terhadap variabel dependen, sebaliknya, jika $a>0,05 \mathrm{H}_{\mathrm{o}}$ diterima dan $\mathrm{H}_{\mathrm{a}}$ ditolak, yang berarti bahwa suatu variabel independen tidak mempunyai pengaruh yang signifikan terhadap variabel dependen.

Dari tabel 7 dapat dilihat bahwa koefisien BI Rate sebesar 0.027573 yang berarti bahwa setiap kenaikan 1 persen BI Rate akan meningkatkan PDB sebesar 0,03 persen. Selain itu, diperoleh $p$-value sebesar $0,0007<a=0,05$, maka kita menolak Ho. Dengan demikian tingkat suku bunga Bank Indonesia secara parsial berpengaruh signifikan terhadap PDB dalam mendorong pertumbuhan ekonomi yang berarti menolak hipotesis kedua.

Selama masa observasi tahun 2011-2015 dapat diamati mulai dari sisi PDB sejak tahun 2011 sampai dengan tahun 2015 menunjukkan adanya peningkatan PDB setiap tahun meskipun jika dilihat dari sisi pertumbuhannya terjadi tren penurunan (lihat tabel 1)

Sebaliknya dari sisi perkembangan suku bunga acuan Bank Indonesia (lihat tabel 8) dapat dilihat bahwa secara rata-rata tahunan mulai dari tahun 2011-2015 BI Rate berada pada level yang cukup tinggi meskipun pada tahun 2012 secara rata-rata sempat berada pada level 5,77 persen yang kemudian beranjak naik pada tahun berikutnya hingga berada di atas level 7 persen. Berdasar fakta ini dapat dikatakan bahwa meskipun BI rate berada tingkat suku bunga yang cukup tinggi, PDB tetap mengalami kenaikan secara agregat. Hal ini dapat dikaitkan dengan kondisi perekonomian emerging markets/countries dalam hal ini termasuk Indonesia pasca terjadinya krisis di Amerika Serikat pada tahun 2008 yang mewabah menjadi krisis global 2008 (subprime mortgage crisis), saat kondisi perekonomian Amerika Serikat mulai membaik secara perlahan sebagai dampak dari stimulus pertumbuhan ekonomi yang diberikan oleh pemerintah Amerika Serikat melalui kebijakan Quantitate Easing, kemudian Bank Sentral Amerika 
Serikat (Federal Reserve Bank) secara bertahap meningkatkan suku bunga acuannya (Federal Funds Rate/FFR) untuk menarik kembali modal dan investasi asing ke Amerika Serikat.

Tabel 8. Perkembangan BI Rate (\%)

\begin{tabular}{|l|c|c|c|c|c|c|c|c|c|c|c|c|r|}
\hline Tahun & Jan & Feb & Mar & Apr & Mei & Jun & Jul & Agu & Sep & Okt & Nov & Des & Rata-rata \\
\hline 2011 & 6.50 & 6.75 & 6.75 & 6.75 & 6.75 & 6.75 & 6.75 & 6.75 & 6.50 & 6.50 & 6.00 & 6.00 & 6.56 \\
\hline 2012 & 6.00 & 5.75 & 5.75 & 5.75 & 5.75 & 5.75 & 5.75 & 5.75 & 5.75 & 5.75 & 5.75 & 5.75 & 5.77 \\
\hline 2013 & 5.75 & 5.75 & 5.75 & 5.75 & 5.75 & 6.00 & 6.50 & 7.00 & 7.25 & 7.25 & 7.50 & 7.50 & 6.48 \\
\hline 2014 & 7.50 & 7.50 & 7.50 & 7.50 & 7.50 & 7.50 & 7.50 & 7.50 & 7.50 & 7.50 & 7.75 & 7.75 & 7.54 \\
\hline 2015 & 7.75 & 7.50 & 7.50 & 7.50 & 7.50 & 7.50 & 7.50 & 7.50 & 7.50 & 7.50 & 7.50 & 7.50 & 7.52 \\
\hline
\end{tabular}

Sumber : Bank Indonesia

Hal inilah yang membuat Bank Indonesia bereaksi dengan salah satu kebijakannya menahan BI Rate pada tingkatan tertentu dalam upaya untuk mencegah ataupun menahan terjadinya pembalikan modal (sudden reversal) dan investasi keluar dari Indonesia (capital flight / outflow) sehingga Bank Indonesia berinisiatif menahan BI Rate pada level yang cukup tinggi yang terlihat mulai dari memasuki triwulan III tahun 2013 sampai dengan akhir tahun 2015 yang berada range 6,50 persen sampai dengan 7,50 persen. Tentunya tingkat suku bunga BI yang cukup tinggi ini cukup mengecewakan bagi pelaku dunia usaha sektor-sektor ekonomi karena kebijakan moneter yang cukup ketat tersebut akan berpotensi membuat sulit mendapatkan kredit murah dari perbankan. Namun adanya arah kebijakan pemerintah untuk meningkatkan pertumbuhan pada masing-masing sektor ekonomi khususnya sektor prioritas pemerintah tentu saja tidak akan cukup jika hanya mengandalkan pembiayaan modal dari penyaluran kredit perbankan saja tetapi juga membutuhkan dukungan capital inflow seperti Foreign Direct Investment (FDI) ataupun modal asing lainnya dalam upaya mendorong perkembangan sektor-sektor ekonomi tersebut yang juga berarti bahwa hal ini memerlukan koordinasi kebijakan antara pemerintah dengan Bank Indonesia dalam hal ini selaku otoritas yang dapat mengatur tingkat suku bunga acuan Bank Indonesia.

Tetapi jika kembali melihat total agregat PDB selama periode observasi pada penelitian menunjukkan peningkatan setiap tahunnya meskipun secara pertumbuhan mengalami tren penurunan, maka hasil estimasi model pada penelitian ini yang menjelaskan bahwa BI Rate memiliki hubungan positif dengan peningkatan PDB dalam menjaga pertumbuhan ekonomi nasional tetap berada pada level moderat di kisaran 5,51 persen selama periode 5 tahun tersebut menjadi cukup jelas.

Sebagai penjelasan tambahan, dapat dikatakan juga bahwa upaya Bank Indonesia untuk mengurangi atau menjaga terjadinya capital outflow secara simultan melalui instrumen kebijakan moneternya tersebut cukup tepat karena pemerintah Indonesia sedang berupaya meningkatkan infrastrukturnya terkait masalah konektivitas antar daerah saat ini serta sektor-sektor prioritas pemerintah lainnya. Hal ini tentunya termasuk faktor-faktor penentu yang dapat 
meningkatkan pertumbuhan ekonomi nasional, selain itu perlu diperhatikan juga bahwa aliran modal masuk (capital inflow) yang lebih bersifat permanen seperti Foreign Direct Investment (FDI) juga dapat terdorong meningkat apalagi karakter jenis aliran modal ini tidak dapat dengan mudah cepat keluar Indonesia apabila terjadi perubahan atau aneka shocks lainnya pada dinamika perekonomian nasional.

\section{Uji Hipotesis Ketiga (H3)}

H3 : Pertumbuhan kredit sektoral dan BI Rate secara bersama berpengaruh terhadap pertumbuhan ekonomi

\section{Pembahasan Hasil Uji Hipotesis Ketiga}

Uji hipotesis ketiga dilakukan dengan Uji-f, sebagaimana dapat dilihat pada tabel 7 , terlihat bahwa $p$-value $f$ statistic sebesar $0,000000<\alpha=0,05$, maka variabel independen (kredit sektoral, dan suku bunga Bank Indonesia) secara bersama-sama mempunyai pengaruh signifikan terhadap variabel dependen (pertumbuhan ekonomi/PDB) yang berarti meenrima hipotesis ketiga, sehingga dapat disimpulkan bahwa model regresi yang diestimasi layak digunakan untuk menjelaskan pengaruh suku bunga Bank Indonesia dan kredit sektoral terhadap PDB atau pertumbuhan ekonomi Indonesia.

Penjelasan hasil uji H3 ini dapat diamati selama periode observasi 20112015 bahwa adanya penyaluran kredit pada sektor-sektor ekonomi serta instrumen kebijakan moneter yang dilakukan oleh Bank Indonesia melalui penetapan BI Rate pada level tertentu memiliki dampak pada peningkatan agregat PDB. Lebih lanjut pada periode ini dapat dilihat bahwa rata-rata tahunan mulai dari tahun 2011-2015 suku bunga acuan Bank Indonesia berada pada level yang cukup tinggi meskipun pada tahun 2012 secara rata-rata sempat berada pada level 5,77 persen yang kemudian beranjak naik pada tahun berikutnya hingga berada di atas level 7 persen dan pada masa tersebut juga dapat dilihat bahwa penyaluran kredit modal kerja dan kredit investasi pada 16 sektor ini dari tahun ke tahun semakin meningkat meskipun terdapat tiga sektor yang justru mengalami penurunan yaitu sektor pertambangan dan penggalian, sektor perantara keuangan, dan sektor jasa kemasyarakatan, sosial-budaya, hiburan, dan perorangan lainnya (lihat tabel 3). Kemudian jika ditelusuri pada sisi PDB terjadi peningkatan setiap tahun secara agregat meskipun dari sisi pertumbuhan mengalami penurunan.

\section{Koefisien Determinasi $\left(\mathbf{R}^{2}\right)$}

Pada tabel 4 terlihat bahwa nilai Adjusted R-squared(Mahyus Ekananda, 2015) adalah sebesar 0,789363 . Hal ini berarti bahwa variabel independen yang terdiri dari kredit sektoral, dan BI Rate dapat menjelaskan pengaruhnya terhadap PDB sebesar 78,94 persen sementara 21,06 persen lainnya dijelaskan oleh variabelvariabel lain yang tidak diestimasi pada model penelitian ini sekaligus yang berarti bahwa model pada penelitian ini cukup representatif untuk mengestimasi dampak dari kredit sektoral dan BI Rate terhadap PDB dalam mendorong pertumbuhan ekonomi. 


\section{KESIMPULAN DAN SARAN}

\section{Kesimpulan}

1. Kredit sektoral secara parsial berpengaruh positif dan signifikan terhadap pertumbuhan ekonomi. Hal ini dapat dilihat dari hasil estimasi dengan koefisien sebesar 0.168633 dan $p$-value sebesar $0.0000<a=5 \%$ sehingga hipotesis pertama diterima;

2. BI Rate secara parsial berpengaruh positif dan signifikan terhadap pertumbuhan ekonomi. Hal ini dapat dilihat dari hasil estimasi dengan koefisien sebesar 0.027573 dan p-value sebesar $0.0007<a=5 \%$ sehingga hipotesis kedua ditolak;

3. Kredit sektoral dan BI Rate secara simultan berpengaruh signifikan terhadap pertumbuhan ekonomi. Hal ini dapat dilihat dari hasil estimasi dengan $0.000000<a=5 \%$ serta koefisien determinasi (Adjusted R-squared) sebesar 0,789363 yang menunjukkan perubahan PDB/pertumbuhan ekonomi sekitar 78,94 persen dipengaruhi oleh variabel-variabel independen pada model ini, sehingga hipotesis ketiga diterima

Saran bagi Otoritas Moneter (Bank Indonesia) dan Otoritas Perbankan dan IKNB (Otoritas Jasa Keuangan)

1. Bank Indonesia harus selalu secara tegas dan konsisten dalam penerapan stance atau sikapnya terkait kebijakan moneter dalam hal ini penetapan BI 7day (Reverse) Repo Rate dengan mengingat lesson learnt dari implementasi BI Rate yang sebelumnya kurang berjalan efektif sebagai suku bunga acuan bagi sektor perbankan di Indonesia. Instrumen BI 7-Day Repo Rate yang sudah berlaku efektif sejak 19 Agustus 2016 agar senantiasa dimonitor secara aktif khususnya terkait hubungannya pada suku bunga pasar uang, sektor perbankan dan sektor riil. Khusus untuk suku bunga pada sektor perbankan karena selama ini terkesan bank-bank tidak melakukan penyesuaian dengan cepat sesuai suku bunga kebijakan yang telah ditetapkan Bank Indonesia;

2. OJK agar tetap konsisten dalam meregulasi industri jasa keuangan agar tetap dapat beroperasi dengan sehat sehingga dibutuhkan pengawasan atas governance untuk operasional perbankan dan nonbank, karena perkembangan sektor-sektor ekonomi yang bermuara pada pertumbuhan ekonomi juga diharapkan dapat didorong dari penyediaan likuiditas melalui penyaluran kredit oleh industri jasa keuangan khususnya sektor perbankan;

3. Sinergi antara BI, OJK dan pemerintah dalam implementasi financial inclusion dalam hal ini terkait penyediaan stimulus seperti kredit bagi UMKM karena dapat meningkatkan lapangan pekerjaan kemudian hal ini tentunya dapat meningkatkan daya beli masyarakat yang selanjutnya diharapkan dapat mendorong pertumbuhan ekonomi nasional.

\section{Saran bagi Pemerintah}

1. Pentingnya sinergi antara otoritas fiskal dan otoritas moneter karena secara praktik global sinergi dari dua jenis otoritas ini dapat menjaga keberlanjutan pertumbuhan ekonomi melalui kebijakan-kebijakan yang terharmonisasi dan saling menuju tingkat perekonomian yang stabil; 
2. Kesamaan pandangan antara pemerintah dan Bank Indonesia harus senantiasa dijaga misalnya apabila pemerintah dalam hal ini Kementerian Keuangan selaku otoritas fiskal menginginkan sektor-sektor ekonomi dapat didorong lebih cepat tentunya tidak akan cukup hanya melalui stimulus fiskal, tetapi juga harus terjadi penurunan suku bunga pinjaman yang berarti BI harus menurunkan BI Rate (per 19 Agustus 2016 BI sudah mengimplementasikan instrumen BI 7-Day Repo Rate) tetapi tetap harus memperhatikan laju inflasi;

3. Memfokuskan pada belanja-belanja yang produktif seperti pada pembangunan infrastruktur untuk meningkatkan konektivitas antar daerah di Indonesia infrastruktur selain dapat mendorong peningkatan output dan percepatan laju pertumbuhan ekonomi ke depan. Perlu diingat bahwa ketersediaan infrastruktur dan sumber energi yang memadai akan menjadi insentif bagi peningkatan aktivitas ekonomi dan investasi pada masa mendatang dan sektor pendidikan yang dapat meningkatkan Indeks Pembangunan Manusia yang juga memiliki pengaruh pada peningkatan kapasitas output yang dapat mendorong pertumbuhan ekonomi nasional;

4. Khusus untuk sektor-sektor ekonomi atau lapangan usaha yang banyak memperkerjakan tenaga kerja agar industri pada sektor-sektor tersebut dapat lebih diproteksi khususnya yang memiliki kerentanan tinggi terhadap dampak krisis ekonomi global;

5. Menjaga stabilitas ekonomi makro dengan karena hal ini terkait erat dengan masalah inflasi dan stabilitas nilai tukar. Langkah-langkah untuk menjaga tingkat inflasi nasional pada dasarnya akan didukung oleh kebijakan bersifat struktural yaitu melalui peningkatan kapasitas produksi nasional (baik bahan pangan dan kebutuhan lainnya) serta perbaikan infrastruktur untuk menjamin distribusi barang kebutuhan ke seluruh wilayah;

6. Khusus untuk pemerintah daerah harus senantiasa bersikap sebagai salah satu ujung tombak pelaksanaan pembangunan salah satunya dengan dapat mengelola alokasi dana dari pemerintah pusat (transfer ke daerah dan dana desa) secara optimal. Pengelolaan anggaran tersebut secara efektif dan efisien akan dapat mendorong percepatan pembangunan di seluruh daerah di Indonesia yang nantinya dapat berujung pada akselerasi pertumbuhan ekonomi secara nasional.

\section{Saran bagi Pelaku Industri Perbankan}

1. Komitmen dalam menyalurkan kredit pada sektor-sektor prioritas ekonomi pemerintah. Selain itu, perlu diperhatikan agar suku bunga kredit perbankan dapat menyesuaikan dengan cepat dengan suku bunga acuan yang telah ditetapkan Bank Indonesia. Hal ini dimaksudkan agar jangan hanya berorientasi pada profitabilitas tinggi tapi perlu memerhatikan kontribusi dalam menstimulus pertumbuhan ekonomi nasional dengan pembiayaan sektor-sektor unggulan tersebut;

2. Prinsip kehati-hatian dalam penyaluran kredit agar senantiasa dipegang teguh untuk mencegah risiko sistemik perbankan yang dapat merusak tatanan perekonomian nasional. 


\section{Saran untuk Penelitian Selanjutnya}

1. Terkait penelitian berikutnya dalam mengestimasi variabel-variabel yang mempengaruhi pertumbuhan ekonomi perlu menambahkan beberapa variabel tambahan seperti kenaikan penghasilan tidak kena pajak (PTKP) yang dapat mendorong tingkat konsumsi masyarakat ataupun besaran agregat konsumsi tersebut, belanja pemerintah, Foreign Direct Investment (FDI), tingkat inflasi, ekspor, dan juga perlu dikaji mengenai perkembangan ekonomi global yang juga memiliki dampak pada pertumbuhan ekonomi Indonesia;

2. Menambah periode observasi sehingga hasil penelitian menjadi lebih komprehensif dalam menggambarkan faktor-faktor yang mempengaruhi pertumbuhan ekonomi Indonesia;

3. Apabila variabel kredit sektoral pada penelitian selanjutnya masih tetap digunakan agar dapat dilakukan adjustment pada data tersebut dengan data PDB sektoral sehingga dapat dianalisis pengaruh per komponen masingmasing sektor antara dari sisi penyaluran kredit dengan PDB. Karena pada penelitian ini sudah mengestimasi pengaruh tersebut secara agregat.

\section{DAFTAR PUSTAKA}

Aviliani, et al., "The Impact of Macroeconomic Condition on The Bank's Performance in Indonesia",Buletin Ekonomi Moneter dan Perbankan,17 (4), 2015.

Bank Indonesia, Statistik Perbankan Indonesia, Diakses 14 Januari 2017 dari Otoritas Jasa Keuangan.

http://www.ojk.go.id/id/kanal/perbankan/data-dan-statistik/statistikperbankan-indonesia/Default.aspx

Bank Indonesia, Peraturan Bank Indonesia Nomor 9/7/PBI/2007 Tentang Perubahan Bank Umum Konvensional menjadi Bank Umum Syariah

Bank Indonesia, Statistik Ekonomi dan Keuangan Indonesia (SEKI), Diakses 14 Januari 2017 dari Bank Indonesia. http://www.bi.go.id/id/statistik/seki/terkini/moneter/Contents/Defa ult.aspx

DamodarNGujarati,DawnC.Porter， Dasar-dasarEkonometrika， (Jakarta:Salemba Empat, 2012)

David, N. Weill, Economic Growth Third Edition (Harlow-Essey:Pearson, 2013)

G.A. Diah Utari, Trinil Arimurti, Ina Nurmalia Kurniati.“Pertumbuhan Kredit Optimal”,Buletin Ekonomi Moneter dan Perbankan,15 (2), 2012.

H. Rachmat Firdaus, Maya Ariyanti, Manajemen Perkreditan Bank Umum, (Bandung:Alfabeta, 2011)

Harmanta "Disintermediasi Fungsi Perbankan di Indonesia Pasca Krisis 1997". Tesis, Fakultas Ekonomi Program Studi Magister Perencanaan dan Kebijakan Publik Universitas Indonesia, Depok, 2005.

I Gusti, Ngurah Agung, Panel Data Analysis Using Eviews (Cichester-WestSussex:Wiley, 2014)

Inggrid."Sektor Keuangan dan Pertumbuhan Ekonomi di Indonesia : Pendekatan Kausalitas dalam Multivariate Vector Error Correction Model (VECM)", Jurnal Ekonomi dan Manajemen,8 (1), 20106. 
Kasmir, Dasar - dasar Perbankan, (Jakarta: Rajawali Pers, 2014)

Lukman Dendawijaya, Manajemen Perbankan, (Ciawi-Bogor:Ghalia Indonesia, 2009)

Mahyus Ekananda, Ekonometrika Dasar untuk Penelitian di Bidang Ekonomi, Sosial dan Bisnis, (Jakarta: Mitra Wacana Media, 2015)

Mahyus Ekananda, Analisis Ekonometrika Data Panel bagi Penelitian Ekonomi, Manajemen, dan Akuntansi, (Jakarta:Mitra Wacana Media, 2014)

Mudrajad Kuncoro, Mudah Memahami dan Menganalisis Indikator Ekonomi, (Yogyakarta: UPP STIM YKPN, 2015)

Mudrajad Kuncoro, Suhardjono, Manajemen Perbankan: Teori dan Aplikasi, (Yogyakarta : BPFE Yogyakarta, 2011)

Olivier, Blanchard, Macroeconomics Seventh Edition (USA-Pearson, 2017)

Ratna Sri Widyastuti, Boedi Armanto."Kompetisi Industri Perbankan Indonesia",Buletin Ekonomi Moneter dan Perbankan,15 (4), 2013.

Rafika Sari "Pengaruh Perkembangan Perbankan terhadap Pertumbuhan Ekonomi Regional di Indonesia Periode Tahun 1987-2002". Tesis, Fakultas Ekonomi Program Studi Magister Ilmu Ekonomi Universitas Indonesia, Depok, 2006

Republik Indonesia, Undang-undang Nomor 10 Tahun 1998 Tentang Perubahan atas Undang-undang Nomor 7 Tahun 1992 tentang Perbankan

Sarah Farahdiba "Pengaruh Kredit Perbankan Terhadap Pertumbuhan Ekonomi Periode Tahun 2005-2009 di Beberapa Daerah di Indonesia". Skripsi, Fakultas Ekonomi Program Studi Ilmu Ekonomi Universitas Hasanuddin, Makassar, 2011

Veithzal Rivai, et al.,Commercial Banking Management : Manajemen Perbankan dari Teori ke Praktik. (Jakarta : Rajawali Pers, 2013).

Wing Wahyu Winarno, Analisis Ekonometrika dan Statistika dengan Eviews, (Yogyakarta:UPP STIM YKPN, 2015)

www.bi.go.id. Diakses 4 Januari 2017

www.bps.go.id. Diakses 14 Januari 2017

www.ojk.go.id. Diakses 14 Januari 2017 